\title{
The Lexical Approach as Known and Utilized by Thai EFL Teachers
}

\author{
Dentisak Dorkchandra (Corresponding author) \\ Department of Thai and Foreign Languages, Kasetsart University \\ 59 Moo 1, Chiangkhrua, Muang district, Sakon Nakhon Province, Thailand \\ Tel: 66-042-725039 E-mail: dentisak@gmail.com
}

Received: March 25, 2016 Accepted: April 12, 2016 Published: April 13, 2016

doi:10.5296/ijele.v4i2.9309 URL: http://dx.doi.org/10.5296/ijele.v4i2.9309

\begin{abstract}
This exploratory research was conducted to investigate the knowledge and utilization of the Lexical Approach (LA) of Thai university EFL teachers in the higher educational institutes in the upper North-eastern parts of Thailand. Specifically, it explored to what extent the teachers know about the LA and utilize it in their classroom practices. The samples were $140 \mathrm{EFL}$ teachers selected by convenient sampling from 9 state universities located in 8 provinces in the region. A close-ended questionnaire with a 5-point-Likert scale was used to collect the data which were analyzed using descriptive statistics. The findings showed that the teachers possessed a moderate level of knowledge about the LA and they utilized the LA in terms of exercises and activities also at a moderate level. The findings were discussed in relation to the LA being unpopular in Thailand due to some factors that might hold back the teachers' interest in utilizing the LA exercises and activities, including other traditional approaches embedded in commercial ELT books and some LA exercises and activities as time-consuming and daunting tasks. Pedagogical implications for the use of the LA in EFL classroom practices and recommendations for future research were provided.
\end{abstract}

Keywords: Lexical Approach (LA), Knowledge and Utilization, Thai EFL Teachers 


\section{Introduction}

According to Baker (2012), "English is perceived as an essential lingua franca which links Thailand culturally, intellectually and commercially with other ASEAN countries and the rest of the world" (p.2). However, even with the launch of AEC (Asean Economic Community) which upholds the lingua franca status of English by having it clearly stipulated in its Charter that English is the working language of the AEC, the English language competence of Thais is still very low in comparison with other ASEAN countries, let alone other 70 countries surveyed by EF English Proficiency Index 2015. (EF EPI, 2015). Moreover, according to the Test and Score Data Summary for TOEFL iBT Tests (ETS, 2015), the average TOEFL test score of Thailand is 74, slightly better than that of Laos and Cambodia which enjoyed 64 and 69 respectively. To this end, numerous suggestions have been provided to the authorities concerned, among which an urgent plan to improve the English skills of both students and teachers, publication of small books with 1,000 often-used English vocabulary words, and a one-month "train-the-trainer' program for the English teachers across the country, emerged as a package of urgent measures. This latest movement is nothing new because, in fact, to address this linguistic problem, the Ministry of Education has over the last two decades at least promoted the implementation of CLT in Thai English classrooms. Still the CLT in Thailand, like other EFL situations elsewhere, is replete with problems because most Thai students cannot function effectively in English. Thai EFL learners' ineffective English performance could be attributed to several factors, and one important factor that is often referred to is the negligence of teaching vocabulary with the emphasis on collocations and their awareness (Wangsirisombat (2011). In fact, one teaching approach that emphasizes collocations as vital part of English vocabulary is the Lexical Approach (LA). However, it remains unclear whether the approach is popular among Thai EFL teachers, especially the university teachers even when some research strongly encouraged applying the LA (Boonyasaquan, 2006; Mallikamas \& Pongpairoj, 2005).

It is unquestioned that effective communication in English, both spoken and written, centers on vocabulary which is widely regarded as the heart of language competence (Wilkins, 1972; Lewis, 1993). If EFL learners know sufficient vocabulary, they are expected to produce meaningful language, hence effective communication. However, before the learners can be successful in learning vocabulary and subsequent using it for effective communication, they need to be trained by teachers who possess good content and pedagogical knowledge because this has a direct effect on the students' performance (Azma \& Talebinejad, 2012; Burns, 1992; Rahimi, Momeni, \& Nejati, 2011). According to Faez (2011), effective EFL teachers must have knowledge base which includes expertise, understanding, awareness, and skills. In the realm of the Lexical Approach which is regarded as the alternative to CLT, effective teachers must know what it is, what salient features there are in it, and what is to do to implement it in classrooms.

While the studies of teacher pedagogical knowledge about the lexical approach and subsequent utilization of the knowledge have been conducted in many contexts, the Thai EFL context has, to date, not been sufficiently done. Given the importance of teachers' pedagogical knowledge and its subsequent utilization, this study sought to address the 
following two research questions:

1. To what extent do Thai EFL teachers know about the Lexical Approach?

2. To what extent do Thai EFL teachers utilize the LA exercises and activities in their classroom practices?

Upon finding the answers to these questions, it was expected that more lights would be shed on the LA as possessed and utilized by Thai university EFL teachers. The findings would help confirm or reject the claim that the LA was unpopular among Thai EFL teachers, and considerably contribute to the literature in the field of EFL/TEFL pedagogy.

\section{Literature Review}

\subsection{Importance of Vocabulary Knowledge}

"If language structures make up the skeleton of language, then it is vocabulary that provides the vital organs and the flesh." (Harmer, 1991, p.153) The preceding sentence clearly stresses the importance of vocabulary which makes a language function and become meaningful. If a person knows only grammar without proper vocabulary knowledge, successful communication cannot be expected. This notion, being equally true for first language (L1) and second language (L2), is in line with what Wilkins (1972) said that, "Without grammar very little can be conveyed; without vocabulary nothing can be conveyed". (p.111). Supporting the above-mentioned notion, L2 learners and teachers perceive vocabulary as the number one priority in L2 learning and teaching (Knight, 1994; Marcaro, 2003). In terms of reading comprehension, the amount of familiar and unfamiliar vocabulary is one of the most significant elements in discerning the comprehension of a text ( $\mathrm{Hu} \&$ Nation, 2000). Similarly, in terms of listening and speaking, vocabulary is also recognized as a vital component and a good indicator of L2 performance and proficiency and this relationship has been extensively investigated (e.g. Foomani, 2015; Hilton, 2008; Segalowiz \& Freed, 2004). To this end, Schmitt (2000) emphasizes that "lexical knowledge is central to communicative competence and to the acquisition of a second language" (p. 55)

\subsection{The Lexical Approach}

Promulgated by Michael Lewis (1993), the Lexical Approach is a particular vocabulary teaching approach. According to Lewis, The LA emphasizes developing learners' proficiency with lexis or words and word combinations. The key principle of the LA is that "language consists of grammaticalized lexis, not lexicalized grammar." This means lexis is central in creating meaning, grammar plays a secondary role in managing meaning. Lexis in this approach is broadly divided into four categories:

1. words or polywords: Words such as pen, teacher; polywords such as by and large, by the way, and

2. collocations: e.g. strong coffee (not powerful coffee, heavy smoker (not strong smoker)

3. semi-fixed expressions: e.g. the purpose of....is to.....; when it comes to.....,...

4. fixed expressions: e.g. There's no accounting for taste. 
Collocations and expressions are deemed as the most important types of lexical phrases or chunks. Native speakers retain many prefabricated lexical items in their memory. L2 learners who wish to achieve language fluency and accuracy have to store, retrieve and combine as many ready-made chunks of language as possible. The ability to chunk language successfully is central to understanding of how language works (Lewis, 1997). Hints on the utilization of the LA are provided by Sethi (2013) as follows:

- Successful language is a wider concept than accurate language. Emphasis is on successful communication not grammatical mastery.

- Language is not learnt by learning individual sounds and structures and then combining them, but by an increasing ability to break down wholes into parts.

- Noticing and recording language patterns and collocations.

- Grammar is acquired by a process of observation, hypothesis and experiment. That is, the Observe-Hypothesis-Experiment cycle replaces the Present-Practice-Produce Paradigm.

- Grammar exploration instead of grammar explanation.

- Intensive and extensive listening and reading in the target language.

- First and second language comparisons and translation carried out chunk-for-chunk, rather than word-for word aimed at raising language awareness.

- Repetition and recycling of activities.

- Guessing the meaning of vocabulary items from context.

- The language activities consistent with a lexical approach must be directed toward naturally occurring language and toward raising learners' awareness of the lexical nature of language.

- Working with dictionaries and other reference tools.

\subsection{Teachers'Pedagogical Knowledge and Student Achievement}

It is as plain as day that effective teachers, whether in the field of language or others, need to master at least two types of basic knowledge before they can function effectively in classrooms; that is content knowledge and pedagogical knowledge. Content knowledge refers to the knowledge a teacher should have in the subject per se while the later refers to the teaching and learning of subjects and their curricula. More specifically, Day (1993) opines that to be effective in L2 teaching, EFL teachers need to possess pedagogical knowledge which consists of knowledge of teaching practices; e.g. classroom management, lesson planning, etc. According to Guerriero (2011), pedagogical knowledge refers to the specialized knowledge of teachers for creating effective teaching and learning environments for all students. The definition given by Guerriero seems fitting in the present investigation though various terms are used in literature to describe teachers' pedagogical knowledge. These include action oriented knowledge (Carter, 1990) which refers to the knowledge for immediate use in teaching practices; personal practical knowledge (Marland, 2001) meaning it is dialectical, situated, and dynamic; and professional craft knowledge (Shimahara, 1998) which considers a specific component of knowledge as the product of teachers' practice experience. 


\section{MlMacrothink}

International Journal of English Language Education

ISSN 2325-0887

2016, Vol. 4, No. 2

Generally, research has shown the relationship between teachers' pedagogical knowledge and students' success (e.g. Azma \& Talebinejad, 2012). Several empirical research findings indicated that higher level of pedagogical knowledge of teachers led to higher students' achievement. In the field of English as a foreign language in particular, studies have found relationship between EFL teachers' pedagogical knowledge and students' achievement in terms of grammar (Andrews, 1994; Borg, 1998), writing (Burns, 1992, Tang, 2012; Tusi, 1996), as well as reading and vocabulary instruction (Rahimi, Momeni \& Nejati, 2011). In respect of the LA with some of its aspects being emphasized for teaching, such as noticing collocations and raising awareness of them (Dorkchandra, 2015; Soleimani, Jafarigohar, \& Iranmanesh, (2013), the learners were found to be successful and attribution could be made as having a link to the teachers' sound pedagogical knowledge.

From the reviewed studies, it was found that most of previous research investigated the effect of the LA on EFL/ESL learners' achievement in the four skills of listening, speaking, reading, and writing. Many research works focused on a particular aspect of the LA such as collocations and explore the application of them in various contexts, as well as error analyses of the collocations. However, exploratory studies to investigate the knowledge about the LA as possessed and demonstrated by EFL teachers and to further explore to what extent the LA exercises and activities were utilized were very limited. Especially, in the context of Thailand's university EFL teachers, no literature regarding the knowledge about and utilization of the LA was found.

\section{Methodology}

\subsection{Design}

Given the paucity of research on the issue, an exploratory research design is perceived to be appropriate in the conduct of this study because an exploratory study is an appropriate method about a research problem when there are few or no earlier studies to refer to.

\subsection{Participants}

One hundred and forty Thai EFL teachers (33/23.6\% male and 107/76.4\% female) participated in this study. The teachers ranged in age from 25-56, with those who were over 45 years being the majority (57/41.7\%). Most teachers had Master's degrees (94/67.1\%), and the rest had doctoral degrees (46/32.9\%). Most were lecturers (111/79.3\%), with 24/17.1\% being assistant professors, and 5/3.6\% associate professors. Given their years of English language teaching experience, the samples were put into three groups: a) 0-5 years; b) 6-10 years; c) over 11 years. The samples were chosen according to convenient sampling from 9 state universities located in 8 provinces the upper Northeast of Thailand. The reason for using convenient sampling was because the researcher knew the exact number of the population; that is 156 Thai EFL teachers who were working as full-time lecturers in those universities during the 1 st semester of the 2015 academic year.

\subsection{Instruments}

In order to measure the participants' knowledge and utilization of the Lexical Approach, a questionnaire (in Thai) was developed by the researcher according to the key principles of the Lexical approach and example exercises and activities presented in Lewis (1997)'s 


\section{$\triangle$ Macrothink}

Implementing the Lexical Approach: Putting theory into practice. It comprised two parts. Part I, comprising 10 items, asked about the participants' personal information covering gender, age, educational degree, academic rank, and years of teaching experience. Totaling 36 items, Part II contained three categories: Knowledge about LA, Exercises used, and Activities used. Each category contained 12 positive close-ended statements with a 5-point-Likert's scale based on Dornyei \& Taguchi (2010), i.e. Strongly Agree (SA), Agree (A), Neutral (N), Disagree (D), and Strongly Disagree (SD). The scoring was made to the items such as 5 was given to the highest and 1 to the lowest. That is, from strongly agree to strong disagree. The reliability of the questionnaire was estimated through Cronbach's alpha which was found to be .893 .

Before administering the questionnaire to the main samples, the reliability that was the internal consistency within the questionnaire items was estimated through a pilot study on 10 EFL university teachers who were experienced in education and English teaching. The results of the reliability analysis are presented in Table 1:

Table 1.

\begin{tabular}{|c|c|c|c|}
\hline \multicolumn{4}{|c|}{ Case Processing Summary } \\
\hline & & $\mathrm{N}$ & $\%$ \\
\hline \multirow{3}{*}{$\begin{array}{l}\text { Case } \\
\mathrm{s}\end{array}$} & Valid & 10 & 100.0 \\
\hline & $\begin{array}{l}\text { Exclude } \\
\mathrm{d}^{\mathrm{a}}\end{array}$ & 0 & .0 \\
\hline & Total & 10 & 100.0 \\
\hline
\end{tabular}

As it is depicted in Table 1, ten EFL teachers took part in the pilot study. All the teachers answered the questionnaire items and no one was excluded from the pilot study. Table 2 shows the result of reliability analysis:

Table 2.

\begin{tabular}{|l|l|}
\hline \multicolumn{2}{|c|}{ Reliability Statistics } \\
\hline Cronbach's Alpha & N of Items \\
\hline .893 & 36 \\
\hline
\end{tabular}

The reliability estimated for the 36 items of the questionnaire was .893 . This index was higher than the minimum required (.70) suggesting that the reliability of the LA questionnaire was acceptable.

\subsection{Data Collection and Procedure}

The data collection was launched in the first semester of academic year 2015 during the month of August. The researcher and his assistant team traveled to the 9 universities in the 
upper Isan or Northeast of Thailand to collect the questionnaires that had earlier been sent two weeks in advance by surface mail to the head of each department concerned in the 9 universities. The head of each respective English department or English-related one at each university was asked for cooperation in distributing the questionnaires. The researcher and his team collected the $140(89.74 \%)$ completed questionnaires out of the distributed 156 . The travel to collect the data lasted 3 days.

\subsection{Data Analysis}

To explore the teachers' knowledge of LA, The data collected through the questionnaire were analyzed using the SPSS program (Version 16) to obtain descriptive statistics. Percentage, frequency, means, and standard deviations were obtained to determine the most and least frequent results for each statement in the questionnaire.

\section{Findings and Discussions}

Research Question 1: To what extent do Thai EFL teachers know about the Lexical Approach?

To answer this research question, the participants' responses to the questionnaire were analyzed. There were 12 statements measuring the teachers' knowledge about the LA. For each statement, the responses were coded 5 for "strongly agree", 4 "agree", 3 "uncertain", 2 "disagree", and 1 "strongly disagree". The mean scores were interpreted according to the following levels of knowledge: 4.50-5.00 = "very high", 3.50-4.49 = "high", 2.50-3.49= "moderate", 1.50-2.49 = "low", and 1.00-1.49 ="very low".

Table 3 demonstrates the main findings related to this question. The mean scores of all items ranged from 3.95 to 2.71 . The first highest result $(M=3.95$, S.D. $=.79)$ highlighted the fact that the participants acknowledged that teaching English through the LA requires various exercises and activities. The second highest result $(\mathrm{M}=3.92$, S.D. $=.67)$ indicates the teachers' knowledge about another important aspect of the LA; That is noticing and teaching learners to notice is the heart of vocabulary teaching. Acknowledge of vocabulary as the basis of successful communication is demonstrated in the third highest mean $(\mathrm{M}=3.89$, S.D. $=.71$ ). However, the overall mean is 3.37 , indicating that, on the whole, the teachers had moderate level of knowledge about the LA.

Table 3. Thai EFL Teachers' Knowledge about the Lexical Approach $(\mathrm{n}=140)$

\begin{tabular}{lccc}
\hline \multicolumn{1}{c}{ Statements } & M & S.D. & Meaning \\
\hline 1. The basis of language competence is vocabulary, but not grammar. & 3.09 & .85 & Moderate \\
2. The basis of successful communication is vocabulary & 3.89 & .71 & High \\
3. Effective communication is more important than just an ability to write and & 3.20 & 1.01 & Moderate
\end{tabular}
compose correct sentences. 
4. The listening skill should be more emphasized than other skills because it is

3.59 2016, Vol. 4, No. 2

vital to language acquisition.

5 .Lexis in itself is correctly grammaticalized, hence not lexicalized grammar.

6 .Vocabulary must be learned in chunks, but not in separate items.

7 .The heart of language teaching is to teach learners to raise awareness and to develop.

8. Noticing and teaching learners to notice is the heart of vocabulary teaching.

9 .Teaching English through the Lexical Approach requires various exercises and activities.

10 .Teaching through the Lexical Approach requires authentic materials.

11 .Teaching vocabulary has to focus more on meaning than context.

12. A syllabus must contain collocation as its core because collocation leads to language competence.

$\begin{array}{rrc}2.99 & .80 & \text { Moderate } \\ 3.56 & .78 & \text { High } \\ 3.33 & .86 & \text { Moderate }\end{array}$

$3.92 \quad .67 \quad$ High

$3.95 \quad .79 \quad$ High

$3.29 \quad .75 \quad$ Moderate

$2.71 \quad 1.08$ Moderate

$2.96 \quad .70 \quad$ Moderate

Overall

3.37

0.82 Moderate

This moderate level of knowledge about the LA might be attributed to the teachers' discrepancies in educational background and years of teaching experience. Since most of the teachers who completed the questionnaires held masters $(94 / 67 \%)$, while only 46 teachers held doctorates, many of them might not have studies as extensively as the doctorate holders in terms of pedagogical approaches and theories. It is believed that doctoral degree holders, due to their extensive reading experience, should possess higher level of knowledge about pedagogical knowledge than Master's degree holders.

The first highest results are in compliance with Macaro (2003) who found that L2 teachers acknowledged that vocabulary was the first priority in language teaching. The participants in this study, when recognizing the importance of vocabulary, emphasized noticing and teaching learners to notice as well as using various exercises and activities to the optimum as a result. This can be considered as knowledge consistency on their part. However, the moderate level of knowledge about the LA as found in this study indicates that the EFL teachers in the upper Northeast of Thailand were far from being described as "well-versed" about the Lexical Approach. They might have read about or studied the LA, but might not have done in details since the approaches to English language teaching are actually abundant in number. This finding is also in line with what Harwood (2002) described in his work that "The Lexical Approach is bandied about by many, but, I suspect, understood by a few.” (p.1)

Gatbonton (2008) found in her study that in terms of content and pedagogical knowledge, novice and experienced teachers are comparable in terms of major categories, but not in terms of details within those categories. This supports what is found in this study when considering the answer to research question 2.

Research question 2: To what extent do Thai EFL teachers utilize the LA exercises and activities in their classroom practices? The mean scores from the questionnaire with 24 
statements (12 statements on the exercises, and 12 on the activities) were analyzed and interpreted according to the following frequency of use: 4.50-5.00 = "most frequently used", 3.50-4.49 = "frequently used", 2.50-3.49 = "moderately used", 1.50-2.49 = "less frequently used", and 1.00-1.49 ="least frequently used". Tables 4 and 5 list the major findings to this research question.

Table 4. The LA Exercises Utilized by Thai EFL Teachers $(n=140)$

\begin{tabular}{|c|c|c|c|}
\hline Exercises & $\mathbf{M}$ & S.D. & Meaning \\
\hline 1. Complete the sentences with the correct words from the list. & 4.66 & .60 & Most frequently used \\
\hline .2 Choose the word partnership that forms the correct collocation. & 2.86 & .86 & Moderately used \\
\hline .3Choose one word that collocates with other words. & 3.41 & .65 & Moderately used \\
\hline 4. Rearrange the jumbled sentences with the correct collocations. & 3.21 & .83 & Moderately used \\
\hline 5. Identify one word which is wrongly used and correct it. & 2.91 & .86 & Moderately used \\
\hline 6. Match sentence heads and their endings. & 2.74 & .87 & Moderately used \\
\hline 7. Match the correct word or phrases. & 4.56 & .66 & Most frequently used \\
\hline 8. Identify the word or phrase which means differently. & 2.44 & .74 & Moderately used \\
\hline 9Choose the sentence or phrase as heard being read out by the teacher. & 1.53 & .69 & Less frequently used \\
\hline 10. Use one word to complete the sentence and add one more word & 2.02 & .97 & Less frequently used \\
\hline 11. Categorize the sentences according to emotional language use. & 1.11 & .31 & Least frequently used \\
\hline $\begin{array}{l}\text { 12. Based on the given situation, search for the most appropriate } \\
\text { expression for the situation, and render it into Thai. }\end{array}$ & 1.79 & 1.00 & Less frequently used \\
\hline Overall & 2.77 & .76 & Moderately used \\
\hline
\end{tabular}

As shown in Table 4, the mean scores of all the items range from 4.66 to 1.11. The first two highest means indicate that the most frequently used exercises based on the LA are sentence completion with word choices given in the list $(\mathrm{M}=4.66)$ and word/phrase matching $(\mathrm{M}=$ 4.56). The third highest mean score $(M=3.41)$ shows that the teachers opted for another form of pairing or matching exercise which requires the learners to choose one word that collocates with other words. Interestingly, it was found that the exercise that requires the categorization of sentences according to emotional language use was the least frequently used $(\mathrm{M}=1.11)$. The overall mean is 2.77 which indicated that, on the whole, the teachers utilized the exercises based on the LA at a moderate level.

Table 5. The LA Activities Utilized by Thai EFL Teachers $(n=140)$

\begin{tabular}{|c|c|c|c|}
\hline Activities & $\mathbf{M}$ & S.D. & Meaning \\
\hline 1. Having the learners search for and underline lexical chunk patterns in a text & 3.44 & .56 & Moderately used \\
\hline
\end{tabular}


2. Having the learners read a text and notice words by underlining them.

3. Having the learners practice noticing how a word is used by searching for collocations in a corpus.

4. Having the learners look up words and compare their examples of use in a corpus and a dictionary.

5. Having the learners match paragraphs and their headings.

6. Having the learners read a text and fill in a recreated partially-filled sentence with a word from the text.

7. Having the learners discuss in what situation an expression containing particular keywords is used. For example: I can't make head nor tail of this.

8. Having the learners play crossword games.

9 .Having the learners fill in the blank with the word they heard.

10. Having the learners react to a text by asking questions.

11. Having the learners compare a translation from one language to another.

12. Having the learners keep a lexical notebook.
2.93

$2.41 \quad .99$

Moderately used

9 Less frequently

used

$2.50 \quad .97 \quad$ Moderately used

$2.66 \quad 70 \quad$ Moderately used

$2.36 \quad 64$ Less frequently

used

$2.04 .66 \quad$ Less frequently

used

$2.54 \quad 67$ Moderately used

$2.06 \quad .26$ Less frequently

used

$4.14 \quad 46 \quad$ Frequently used

$2.95 \quad 77 \quad$ Moderately used

$2.32 .76 \quad$ Less frequently

used

It was found in Table 5 that, overall, the teachers utilized the LA in their classroom activities also at a moderate level $(\mathrm{M}=2.70$, S.D. $=.66)$. The activities they utilized frequently included item $10(\mathrm{M}=4.14$, S.D. = .46) (Having the learners react to a text by asking questions). Other items with quite high mean included item $1(\mathrm{M}=3.44$, S.D. = .56) (Having the learners search for and underline lexical chunk patterns in a text such as Adjective + noun), item $11(\mathrm{M}=2.95$, S.D. $=.77)$ (Having the learners compare a translation from one language to another, and item $2(\mathrm{M}=2.93$, S.D. $=.37)$ (Having the learners read a text and notice words by underlining them)

That the teachers in this study had moderate level of knowledge about the LA is in consistence with their moderate level of utilization of the exercises and activities. It clearly indicates the LA was not popular among Thai university EFL teachers. In light of English language teaching, approaches abound and it cannot be said which approach is the best single one among others. For maximum effectiveness, a combination of several approaches can be utilized simultaneously. In this regard, though it has been around for over 20 years, the Lexical Approach might not seem interesting to some teachers, nor they might have investigated in details which approach is better than the others or what constitutes such and such approaches known under various terminologies. On the other hand, they might have been familiar with their favorite old-aged methods the terminology of which they did not know. The LA per se is, in fact, a lexis-based teaching approach which might not be suitable for the teachers who teach English courses less relevant to incessant use of vocabulary such 
as those of grammar, the teachers' knowledge and utilization of exercises and activities were therefore reported as moderately used.

Lackman (2011) posits that using the Lexical Approach requires the investigation of spoken and written language in order to notice structures that are often ignored because they do not fall into the categories determined by the traditional understanding of grammar. As a consequence, the LA is deemed as a time-consuming and daunting approach. The teachers who want to use the Lexical Approach need to be particularly industrious, deeply careful, and especially like to read and listen attentively. This makes many of them, though recognizing the effectiveness of the LA for communicative language teaching (CLT) opt not to use the approach, but cling to other traditional teaching approaches instead (Padurean, 2014). The finding in this study here concurs with Cole \& Knowles (2000) who found that teachers are knowledgeable, but they do not always use what they know in their teaching.

Other factors might have contributed to the moderate utilization of exercises and activities found in this study. These include lack of confidence and time, much preparation, and appropriate syllabus for the class (Parish, 2011). Prodromou (1996) found that teachers must be well-equipped or sufficiently confident in order to teach authentic English such as the daily expressions. Though collocation is one of the most important elements of the LA, or according to Lewis (1997), the most important of teaching activities, Thai EFL teachers in this study only reported moderate use of collocation-related exercises and activities which included having the learners read a text and underlining or searching collocates and underlining them, for example the adjective + noun collocation, and exploring a corpus to practice noticing language use. This highlighted the fact that the LA was not popular in Thailand as claimed by

Another explanation for the reported moderate use of LA exercises and activities by the teachers in this study could be attributed to the use of commercial textbooks in classroom teaching. To use the Lexical Approach in their exercises or activities especially those relevant to corpora, teachers usually create or prepare their own materials, and this thwarts them, hence unwillingness to use the LA. Most of them, therefore, might have used the commercial books which abound in the ELT market. According to Harwood (2002) commercial ELT textbooks are not made from or based on the Lexical Approach. Similarly, Leo Selivan (2013) wrote that EFL/ELT commercial materials still contain a traditional grammar syllabus, the main object of Lewis's attack, albeit more cleverly disguised. And this might have been the cause of the LA not being widely utilized for the available commercial materials are not conducive to nor designed to encourage the use of the LA.

Though on average the teachers were of moderate knowledge about the LA and utilized the exercises and activities based on the LA at a moderate level, they were found to be different details in terms of the utilization. That is, the teachers with higher educational degrees, higher academic ranks, and more years of teaching experience had better knowledge about the LA, but less frequently used the LA in their classroom exercises and activities especially regarding the corpus-related ones. Those who were mere young lecturers with less teaching experience $(M=2.70)$ used the LA exercises and activities more frequently than those who 
were assistant professors $(M=2.65)$ and associate professors $(M=2.47)$. This is in line with the findings by Asl, et. al. (2014) which indicated that the more aged and experienced EFL teachers become, the less they use theoretical pedagogy in their teaching. The possible explanation for this finding is that the experienced teachers might be saturated in their career work, or they might be already contented with their job status. Therefore, they might not find it necessary to seek new pedagogical knowledge and utilize it in their day-to-day teaching. In the same vein, Moradan \& Pourasadollah (2014) also found in their study that experienced teachers thought knowing about methods and techniques introduced by others are of no use because they may prevent them from developing their own methods. On the other hand, novice teachers emphasized the effectiveness of being aware of different methods, thinking that they can aid in dealing with different situations and guide them in the teaching experience. That the younger teachers with fewer years of teaching experience used more LA exercises and activities could be attributed to some factors such as work drive within their affiliation. For example, in Thailand currently many universities require that new teachers have to produce a certain amount of academic work to achieve at least an assistant professorship within 5 years since their job inception to ensure their employment contract extension. The utilization of the LA exercises and activities as reported in this study might be part of these young and less experienced teachers' endeavor to achievement in their teaching career.

\section{Conclusion}

The researcher of the present study investigated to what extent the Lexical Approach (LA) was known and consequently put into practice by Thai university EFL teachers because it is these teachers that, one way or another, influence the students' English performance. The primary aims of this study were to investigate the extent to which Thai university EFL teachers know about the LA and utilize the LA exercises and activities in their classroom practices. The results from 140 close-ended questionnaires revealed that Thai university EFL teachers in the upper Northeast of Thailand had a moderate level of knowledge about the LA, and moderately utilized the LA exercises and activities. This implied that the LA was not popular among Thai university EFL teachers. This may be attributed to the following factors: they did not study in details about the LA; they were more interested in other teaching approaches which could be deemed less demanding and less time-consuming; Most ELT books are designed based on traditional teaching methods rather than the LA. The moderate use of the LA exercises and activities was therefore interpreted in line with the level of the knowledge the teachers had. The results of this study have important implications for Thai EFL university teachers. First, the teachers who would like to utilize the LA in their classroom practices should consider whether the ELT books available in the book market are designed in the way that the LA is embedded in lessons and relevant activities. Using LA-based commercial materials would help them reduce the time to spend designing and selecting exercises and activities; hence utilization of more LA. Secondly, the utilization of the LA exercises and activities in this study was reported to be focused only on a few formats such as, fill-in-the-blanks, matching, and re-arranging, EFL teachers should utilize more 
various LA exercises and activities especially the corpus-based ones because such exercises and activities which are also based on authentic English would have positive effects on EFL students' learning achievement in all the four skills. Lastly, since the older teachers with longer years of teaching experience were more apathetic to seeking further pedagogical knowledge as compared to the younger teachers, a workshop on the LA and how to use it should be organized. Knowing it better, the targeted teachers would be able to use it more in terms of exercises or activities; hence improved learning achievement on the students' part.

Last but not least, the present study is without limitations which include: First, the participants in this study were Thai university EFL teachers in 8 provinces in the upper Northeast of Thailand. Therefore, the EFL teachers who are in different higher educational institutes may show different outcomes. Second, only the close-ended questionnaire was used to collect the data. Therefore, only the quantitative data were drawn. Qualitative data collected through an open-ended questionnaire and an interview should be included in future research.

Recommendations for future research are as follows:

Future research on the knowledge and utilization of the Lexical Approach should be carried out on a larger scale, for example across the country or the region, to obtain the results in a broader sense.

Future research should include other instruments for collecting both quantitative and qualitative data to investigate the EFL teachers' knowledge about the Lexical Approach and the extent to which it is utilized. The instruments to be used may include an interview and observation.

There should be an investigation into factors such as gender, age, educational degree, academic rank, and years of teaching experience, that might have an association with EFL teachers' knowledge about the Lexical Approach and the extent to which it is utilized.

\section{Acknowledgement}

The research is financed by the Faculty of Liberal Arts and Management Science, Kasetsart University, Thailand.

\section{References}

Andrews, S. (1994). The grammatical knowledge/awareness of native-speaker EFL teachers: What the trainers say. In M. Bygate, A. Tonkyn \& E.Williams (Eds.), Grammar and the Language Teacher (pp. 69-89). London: Prentice Hall International.

Asl, E. S., Asl, N. S., \& Asl, A. S. (2014). The erosion of EFL teachers' content and pedagogical-content knowledge throughout the years of teaching experience. Procedia-Social and Behavioral Sciences 98(2014), 1599-1605.

Azma, M., \& Talebinejad, M. R. (2012). Teachers' pedagogical knowledge and learners' success in EFL contexts. ELT Voices-India, International Electronic Journal for the Teachers 
of English, 2(6), 19-37.

Baker, W. (2012). English as a lingua franca in Thailand: Characterisations and implications. Englishes in Practice, 1, 18-27

Boonyasaquan, S. (2006). The Lexical Approach: An emphasis on collocations. Manutsat Paritat: Journal of Humanities, 28(1), 98-108.

Borg, S. (1998). Teacher's pedagogical systems and grammar teaching: A qualitative study. TESOL Quarterly, 32, 9-38.

Burns, A. (1992). Starting all over again: From teaching adults to teaching beginners. In D. Freeman \& J. C. Richards (Eds.), Teacher Learning in Language Teaching (pp. 154-177). Cambridge: Cambridge University Press.

Carter, K. (1990). Teachers' knowledge and learning to teach. In W. R. Houston (Ed.), Handbook of research on teacher education (pp. 291-310). New York: MacMillan.

Cole, L., \& Knowles J. (2000). Researching teaching: Exploring teacher development through reflexive inquiry. Boston: Allyn \& Bacon.

Day, R. (1993). Models and the knowledge base of second language teacher education. Working papers in second language studies, 11(2), 1-13.

Dorkchandra, D. (2015). The effects of collocation noticing instruction on Thai EFL learners' collocational competence. Journal of Advances in English Language Teaching, 3(1), 1-11.

Dornyei, Z., \& Taguchi, T. (2010). Questionnaires in Second Language Research: Construction, Administration, and Processing (2nd ed.). London: Routledge.

Educational Testing Service. (2015). Test and score data summary for TOEFL iBT Tests. Retrieved from http://www.ets.org (August 20, 2015).

EF, EPI 2015 (2015, December 19). The world's largest ranking of countries by English skills (2015, December 19). Retrieved from http://www.ef.co.th/epi/ (December 22, 2015).

Faez, F. (2011). Points of departure: Developing the knowledge base of ESL and FSL teachers for K-12 programs in Canada. The Canadian Journal of Applied Linguistics, 14(1), 29-49.

Foomani, E. M. (2015). Lexical inferencing in listening: Depth of vocabulary knowledge and listening proficiency. International Journal of English Language Education, 3(2), 106-117.

Gatbonton, E. (2008). Looking beyond teachers' classroom behavior: Novice and experienced ESL teachers' pedagogical knowledge. Language Teaching Research, 12(2), 161-182.

Guerriero, S. (2011). Teachers' pedagogical knowledge and the teaching profession. Project report. Centre for Educational Research and Innovation - CERI. Retrieved from http://www.oecd.org/edu/ceri/Background_document_to_Symposium_ITEL-FINAL.pdf (November 8, 2015). 
Harwood, N. (2002). Taking a lexical approach to teaching: principles and problems. International Journal of Applied Linguistics, 12(2), 139-155.

Hilton, H. (2008). The link between vocabulary knowledge and spoken L2 fluency. Language Learning Journal, 36, 153-166. http://dx.doi.org/10.1080/09571730802389983

Hu, H. C., \& Nation, I. S. P. (2000). Unknown word density and reading comprehension. Reading in Foreign Language, 13(1), 403-430.

Knight, S. (1994). Dictionary use while reading: The effects on comprehension and vocabulary acquisition for students of different verbal abilities. The Modern Language Journal, 78, 285-299.

Lackman, K. (2011). Lexical Approach Activities: A revolutionary way of teaching. Ken Lackman \& Associates Educational Consultants. Retrieved from http://kenlackman.com/files/LexicalActivitiesBook102.pdf (August 15, 2015).

Lewis, M. (1997). Implementing the lexical approach: Putting theory into practice. Hove, UK: Language Teaching Publications.

Macaro, E. (2003). Teaching and Learning a Second Language. New York: Continuum.

Mallikamas, P., \& Pongpairoj, N. (2005). Thai Learners' Knowledge of English Collocations. HKBU Papers in Applied Linguistic Studies, 9, 1-22.

Marland, P. (2001). Teachers' practical theories: Implications for teacher development. In Y. C. Cheng, M. M. V. Mok, \& K. T. Tsui (Eds.), Teaching effectiveness and teacher development: Towards a new knowledge base (pp. 165-182). Hong Kong: The Hong Kong Institute of Education.

Moradan, A., \& Pourasadollah, R. (2014). Teachers' thinking about their teaching: A critical study on Iranian TEFL teachers. Social and Behavioral Sciences, 98, 1194-1203. http://dx.doi.org/10.1016/j.sbspro.2014.03.534

Padurean, A. (2014). Perspectives on teaching English as a second language. Are teachers ready to give up the past? Journal Plus Education, 10(1), 222-231.

Parish, L. (2011). The lexical approach; a systematic way of building oral fluency, JALT2010 conference proceedings, Tokyo.

Prodromou, L. (1996). "Correspondence from Luke Prodromou”. ELT Journal, 50(4), 371-373. http://dx.doi.org/10.1093/elt/50.4.371

Rahimi, M., Momeni, G., and Nejati, R. (2011). The impact of lexically-based language teaching on students' achievement in learning English as a foreign language. Procedia Social and Behavioral Sciences, 31, 31-36. http://dx.doi.org/10.1016/j.sbspro.2011.12.012

Schmitt, N. (2000). Vocabulary in language teaching. Cambridge: Cambridge University Press.

Segalowitz, N., \& Freed, B. F. (2004). Context, contact, and cognition in oral fluency 


\section{Macrothink}

International Journal of English Language Education

ISSN 2325-0887

2016, Vol. 4, No. 2

acquisition. Studies in Second Language Acquisition, 26, 173-199. http://dx.doi.org/10.1017/S0272263104262027

Selivan, Leo. (2013). Why has the lexical approach been so long in coming? The Guardian. Retrieved

from http://www.theguardian.com/education/2013/mar/26/leixical-approach-revolution (July 21, 2015).

Sethi, Deepti. (2013). Lexical Approach: Revisiting English language teaching by putting theories into practice. Research on Humanities and Social Sciences, 3(8), 6-8.

Shimahara, N. K. (1998). The Japanese model of professional development: Teaching as craft. Teaching \& Teacher Education, 14(5), 451-462.

Soleimani, H., Jafarigohar, M., \& Iranmanesh, T. (2013). The effect of collocation awareness-raising on the EAP learners' achievement of academic collocations through writing tasks. International Journal of Language Learning and Applied Linguistics World, 4(3), 256-272.

Staehr, L. S. (2009). Vocabulary knowledge and advanced listening comprehension in English as a foreign language. Studies in Second Language Acquisition, 31, 577-607. http://dx.doi.org/10.1017/S0272263109990039

Tang, J. (2012). An empirical study on the effectiveness of the lexical approach to improving writing in SLA. Journal of Language Teaching and Research, 3(3), 578-583. http://dx.doi.org/10.4304/jltr.3.3.578-583

Tusi, A. B. M. (1996). Learning how to teach ESL writing. In D. Freeman, \& J. C. Richards (Eds.), Teacher learning in language teaching (pp. 97-119). Cambridge: Cambridge University Press.

Wangsirisombat, N. (2011). A study of collocational errors in Thai EFL learners' writing. (Unpublished Master thesis). Srinakarinwirot University, Bangkok, Thailand.

Wilkins, D. A. (1972). Linguistics and Language Teaching. London: Edward Arnold.

\section{Copyright Disclaimer}

Copyright for this article is retained by the author(s), with first publication rights granted to the journal.

This is an open-access article distributed under the terms and conditions of the Creative Commons Attribution license (http://creativecommons.org/licenses/by/3.0/). 